Southern Methodist University

SMU Scholar

Faculty Journal Articles and Book Chapters

Faculty Scholarship

2008

\title{
Christianity and the Legal Status of Abandoned Children in the Later Roman Empire
}

Joshua C. Tate

Southern Methodist University, Dedman School of Law

Recommended Citation

Joshua C. Tate, Christianity and the Legal Status of Abandoned Children in the Later Roman Empire, $24 \mathrm{~J}$. L. \& Religion 123 (2008)

This document is brought to you for free and open access by the Faculty Scholarship at SMU Scholar. It has been accepted for inclusion in Faculty Journal Articles and Book Chapters by an authorized administrator of SMU Scholar. For more information, please visit http://digitalrepository.smu.edu. 


\title{
CHRISTIANITY AND THE LEGAL STATUS OF ABANDONED CHILDREN IN THE LATER ROMAN EMPIRE
}

\author{
Joshua C. Tate*
}

A.H.M. Jones, the great British historian of the later Roman Empire, was once asked what difference conversion to Christianity made to Rome. His answer: None.' Brutal gladiatorial contests continued to be held, slavery was not abolished, and cruel penalties were laid down for seemingly minor moral infractions. ${ }^{2}$ Thus, Jones reasoned, the actual impact of Christianity on secular Roman society is difficult to see. Jones's view, however, has not been universally shared, particularly when it comes to the Roman legal system. Biondo Biondi saw Christianity as bringing about "un profundo rivolgimento" in late Roman law, which had ramifications in many different areas. ${ }^{3}$ As a religion, Christianity differed in unmistakable ways from its pagan competitors, ${ }^{4}$ and it would be quite surprising if these differences did not have some impact on Roman law and society when Christianity was adopted as the official state religion. The late Roman era offers a fertile testing ground for the impact a nascent religion might have on a society and its legal institutions.

* Assistant Professor of Law, Southern Methodist University. I would like to thank Jessica Dixon, Peter Garnsey, Lisa Hasday, Jeffrey Kahn, David Johnston, and Rose Villazor and those who attended my presentation at the $2007 \mathrm{Law}$ and Literature International Colloquium in Swansea for their comments on this essay. I am also grateful for the assistance of Alvin Dong and the research staff of the Biddle Law Library of the University of Pennsylvania Law School, where I had the pleasure of visiting during the Spring 2008 semester, as well as Lynn Murray and the staff of the Underwood Law Library at SMU Dedman School of Law. The research for this essay was funded in part by a generous grant from the Emily Parker Endowed Faculty Research Fund at SMU Dedman School of Law. This essay is dedicated to John Crook, late Professor of Ancient History at the University of Cambridge, who inspired generations of students to study the law and life of Rome.

1. Ramsay MacMullen, Christianizing the Roman Empire (A.D. 100-400), at 154 n. 25 (Yale U. Press 1984).

2. See e.g. Ramsay MacMullen, What Difference Did Christianity Make?, 35 Historia: Revue d'Histoire Ancienne 322, 322-343 (1986). On the legal aspects of the question, see Judith Evans-Grubbs, Law and Family in Late Antiquity: The Emperor Constantine's Marriage Legislation (Oxford U. Press 1995).

3. 1 Biondo Biondi, Diritto Romano Cristiano 1 (Giuffrè 1952) (Italian).

4. See e.g. Peter Brown, The Cult of the Saints 21 (U. Chi. Press 1981); Robin Lane Fox, Pagans and Christians 22 (Knopf 1987). 
This Essay will discuss the possible impact of Christianity in one particular area of late Roman law, namely, imperial legislation dealing with abandoned or exposed children. I will begin by summarizing some historical background as well as previous work on the subject. I will then move on to discuss the Christian religious discourse that was prevalent in the Roman Empire in late antiquity and how it addressed the problem of abandoned children. Next, I will analyze the various imperial constitutions that were issued on the subject from the age of Constantine to that of Justinian. I will argue that the legislation of Constantine was not distinctly Christian in content, but that some Christian influence can be seen in the rhetoric of imperial constitutions beginning in the fifth century, and that Christian ideas seem to have affected both the substance and the rhetoric of Justinian's legislation. Particular emphasis will be given to the use of the word misericordia in a constitution of Honorius to refer to the actions of the collector of abandoned children, as well as the notion, in Justinian's legislation, that adoption entails freedom. I will conclude by drawing an analogy between the legislation of Justinian and modern attempts to regulate the adoption of children. Both the reforms of Justinian and the modern UN Convention on the Rights of the Child have arguably privileged moral over economic arguments concerning children's rights.

The question of the legal status of abandoned children in late antiquity is not a new one, and has been explored by historians for some time. $^{5}$ To some degree, the wealth of literature on the topic can be explained by the fact that the notion of "abandonment" can encompass the sale of children by their parents, an issue treated at length in ancient legal sources. ${ }^{6}$ Even if the issue of simple abandonment or exposure ${ }^{7}$ is

5. For an introductory bibliography, see William V. Harris, Child-exposure in the Roman Empire, 84 JRS 1 n. 2-3 (1994). For the most recent treatment of the issue, see Timothy S. Miller, The Orphans of Byzantium: Child Welfare in the Christian Empire 148-152 (Cath. U. Am. Press 2003).

6. D. 20.3.5; D 21.2.39.3; Sent. Paul. 5.1.1; CJ 8.16(17).I (197); CJ 7.16.1 (Caracalla); CJ 8.16(17).6 (293); CJ 7.16.37 (294); CJ 2.4.26 (294); CJ 4.43.1 (294); Frag. Vat. 33-4 (Constantine); CT 11.27.2 (322); CT 4.8.6 (323); CT 5.10.1 (329?); CJ 4.43.2 (329?); CT 3.3.1 (391); Sirm. Const. 5 (419); Nov. Val. 33 (451). The two issues of sale and exposure are often treated side by side in Roman legal sources, and are also usually discussed together in the modem secondary literature. Cf. Maria Bianchi Fossati Vanzetti, Vendita ed esposizione degli infanti da Costantino a Giustiniano, 49 SDHI 179, 188 (1983) (Italian). I have focused my discussion on issues regarding simple abandonment as opposed to sale.

7. Boswell prefers the term "abandonment" over "exposure," believing that the English word "exposure" conveys "a sense of risk or harm . . . which is absent from the ancient terms." John Boswell, The Kindness of Strangers: The Abandonment of Children in Western Europe from Late Antiquity to the Renaissance 24-25 (Penguin Press 1988). I have used the two terms interchangeably, following Harris, supra n. 5. 
considered apart from the related problem of sale, the precise development of the law over the centuries is far from clear.

One point of consensus in recent scholarship, however, is that the law regarding the exposure of infants was not modified substantially, but merely refined and explained, during the years between Constantine and Justinian. $^{8}$ So long as one is concerned merely with the practical consequences of the law, this assertion is not difficult to sustain, although specific objections could be raised to it. As far as can be ascertained from the sources, following a notable reform under Constantine in $331,{ }^{9}$ several laws were passed on the subject during the fourth and fifth centuries, ${ }^{10}$ but it was not until the reign of Justinian that the legal position of abandoned children was drastically modified. ${ }^{11}$ The picture of the intervening period is altered somewhat once one takes into account not just the practical effects of the laws being passed, but the intellectual discourse that they seem to reflect. Even from an ideological perspective, there is insufficient evidence to prove that the centuries between Constantine and Justinian were a time of radical change. If we are to discern Christian influence in the law, however, its roots are not likely to be found in the legislation of Constantine, as has been previously supposed, but in the new ideological perspective of Justinian's reform as foreshadowed in the fifth century. ${ }^{12}$

In discussing the ideological climate in which late antique laws were written, one cannot avoid coming to grips with the rise of Christianity, which clearly affected the way many people thought about themselves, about each other, and about their God. This is far from saying that Christianity had any significant effect on the way in which people behaved, ${ }^{13}$ or that a single "Christian discourse" held sway in the Mediterranean to the exclusion of all other Christian discourses. ${ }^{14}$ Moreover, the discourse of Christian bishops such as Augustine of Hippo and Ambrose of Milan was not identical to the discourse that

8. Michael Memmer, Ad servitutem aut ad lupanar... Ein Beitrag zur Rechtsstellung von Findelkindern nach römischen Recht-unter besonderer Berücksichtigung von $\$ \xi 77,98$ Sententiae Syriacae, 108 ZRG:RA 79-80 (1991) (German); Vanzetti, supra n. 6, at 202.

9. CT 5.9.1.

10. CJ 8.51(52).2 (374); CT 5.9.2 (412); Sirm. Const. 5 (419).

11. CJ 8.51(52). 3 (529); Nov. Just. 153 (541).

12. Some readers may object to my occasional use of the emperor's name to describe "his" legislation. The convention persists despite our new attentiveness to the complex process by which legislation was created.

13. MacMullen, supra $\mathrm{n} .2$.

14. Averil Cameron, Christianity and the Rhetoric of Empire: The Development of Christian Discourse 5 (U. Cal. Press 1991). Or, for that matter, that paganism did not remain alive and well throughout much of the period. 
thrived in the law schools, despite the likelihood of mutual influence: when Augustine was asked to resolve certain civil suits in his diocese, he did not attempt to pass judgment according to Christian teaching, but rather sought the advice of a layman named Eustochius who was apparently learned in the civil law. ${ }^{15}$ As would become important in his theology, Augustine thus acknowledged a difference between the law of Christ and the law of Rome. ${ }^{16}$

"Orthodox"17 Christian thought likely affected civil legislation on abandoned children in two ways: through direct references to the consequences of abandonment and through general theological ideas presented in other contexts but relevant in an indirect way to the question of exposure. In examining direct discussions, Boswell differentiates between early Christian apologists, ${ }^{18}$ who were primarily concerned with condemning the act of abandonment itself, and later writers, ${ }^{19}$ who more frequently took into account the often desperate circumstances that drove parents to take such a step. ${ }^{20}$

The Christian theologian Lactantius represents a transitional phase between these two periods of thought, and gives a typical Christian description of the act of exposure. ${ }^{21}$ While condemning exposure as tantamount to killing, and referring to the possibility that the exposed child could be attacked by dogs, Lactantius nevertheless recognizes that some abandoned infants actually survived and must be accounted for in Christian thinking, for he points to prostitution and slavery as other possible evils awaiting the unfortunate child. ${ }^{22}$

Unlike most previous Christian writers, however, Lactantius also takes into account the fact that some parents were driven to such a desperate act of exposure by their abject poverty, although he dismisses

15. Augustine, Epistle 24*.

16. The fact that Augustine, as a religious authority, seems to have been engaged in active correspondence with a secular jurist points to a manner in which the two discourses were becoming interlinked. While we should never assume that the views of the church fathers were identical to those of lawyers and imperial officials, it would be equally misguided to suppose that the one had no effect upon the other.

17. Due to the limited source material that has come down to us, this discussion will necessarily focus on the strands of Christianity that later came to be termed "orthodox." This does not imply, however, that other Christian traditions, such as Pelagianism, where not also at certain stages in a position to influence imperial legislation.

18. Such as Athenagoras, Legatio pro Christianis 35 (PG 6.969), Justin Martyr, I Apology 27 (PG 6.369-372), and Minucius Felix, Octavius 31 (PL 3.336-337).

19. In particular Basil of Caesarea, Homilia in Illud Lucae, Destruam 4 (PG 31.268-269), and Ambrose, De Tobia 1.8.29 (PL 14.769-770).

20. Boswell, supran. 7, at 157-172.

21. Id. at 160-161.

22. Lactantius, Divine Institutes 6.20 (PL 6.708-709). 
this as being no excuse. Indeed, he argues that God daily makes the poor rich and that those who cannot afford children ought to abstain from intercourse. ${ }^{23}$ A notable aspect of Lactantius's treatment of exposure, however, is his emphasis on the deed itself and the persons responsible for it, rather than the act of piety on the part of someone else who takes pity on the child and brings it under his or her care.

A focus on the abandoned child's rescuer is especially present in the later Christian sources, but it is usually expressed through allegory and not treated alongside other aspects of abandonment. Discussing the behavior of eagles that had apparently been observed to abandon some of their young, ${ }^{24}$ Ambrose noted that the abandoned eaglets were subsequently rescued and taken under the care of another bird called the fulica $^{25}$ Animal behavior was frequently cited by Christian writers as a model for human morality, ${ }^{26}$ and it is not difficult to see how this metaphor would have been interpreted as an exhortation to take pity on abandoned children.

The corpus of Christian writings yields many other general ideas that may have influenced contemporary views on abandonment. One must be careful, however, not to assume that the same connections a modern historian might make were also present in the minds of ancient thinkers. For example, one Christian tradition that may or may not have been influential concerns the ancestry of Christ. In the New Testament accounts given in Matthew and Luke, Christ's genealogy was reckoned through the ancestors of Joseph, his earthly father, rather than directly from God. ${ }^{27}$ To explain this fact, Christian thinkers like Augustine of Hippo defended Joseph's paternity by praising the institution of adoptive parenthood, using arguments that could have influenced legal notions about the relationship between an abandoned child and the person who collected it. Explaining in a sermon how Joseph's right to be called father was all the more secure because he did not beget Jesus by the flesh, for example, Augustine points to the laws of adoption in defense of his case:

Look, brothers, look at the laws of adoption, by which means a man becomes the son of someone from whose seed he was not born; so that the will of the one adopting has more of a right over him than the nature of the one producing. Therefore Joseph must

23. Id.

24. As noted by Basil of Caesarea, Homilia VIII in Hexaemeron 6 (PG 29.177-180).

25. Hexaemeron 18.61 (PL 14.232).

26. Boswell, supra $\mathrm{n} .7$, at 168.

27. Matt 1:2-17; Luke 3:23-38 (all Biblical citations are taken from the RSV). 
not only be reckoned a father, but most greatly so. ${ }^{28}$

Adoption, argues Augustine, had a long history in the Old Testament. Moses himself was exposed (expositus) by his mother and then adopted (adoptatus) by Pharaoh's daughter; while the ancients did not have the modern legal formulae, "the judgment of the will was held as a rule of law." 29 Augustine is clearly using the story of Moses in order to make a particular rhetorical point, but the possibility that such comments might have influenced contemporary ideas regarding the relationship between expositi and those who collected them cannot be dismissed.

Much closer to the core of Christian teaching relevant to abandoned children are two passages drawn from the New Testament and often discussed by patristic writers. The first, in the gospel of John, speaks of Christ's rejection by his own people and subsequent reception among the believers, who thereby became children of God, not through the flesh, but through God's will. ${ }^{30}$ This passage was interpreted by later writers as referring to the transition whereby the Christians replaced the Jews as God's true children. ${ }^{31}$ According to Ambrose, although the Jews had been originally named as heirs, they could not come into their inheritance, for they had not received adoption by the grace of God. ${ }^{32}$ What this adoption entailed was clarified in a second scriptural passage:

All who are led by the Spirit of God are sons of God. For you did not receive the spirit of slavery to fall back into fear, but you have received the spirit of sonship. When we cry, "Abba! Father!" it is the Spirit himself bearing witness with our spirit that we are children of God, and if children, then heirs, heirs of God and fellow heirs with Christ, provided we suffer with him in order that we may also be glorified with him. ${ }^{33}$

In the view of Ambrose, freedom, grace, adoption, and heirship were inexorably linked: as the Jews did not have the first three, they were sons in name but not in spirit. ${ }^{34}$

28. Augustine, Sermon 51:16 (PL 38.348). Here as elsewhere, I give my own English translation of quotations from the Latin sources.

29. Id. at 51:18 (PL 38.349). The reason for the exposure of Moses, according to the Biblical account, was to protect him from being killed under an Egyptian law ordering that all male Hebrew infants be put to death. Exod 1:16-22.

30. John 1:11-13.

31. Ambrose, Epistle 75 (PL 16.1257-1259); Cyril of Alexandria, Commentarius in $S$. Joannis Evangelium 1:9 (PG 73.149-157).

32. Ambrose, Epistle 75:4 (PL 16.1258).

33. Rom 8:12-17.

34. Ambrose, Epistle 75:5 (PL 16.1258). 
The link between adoption and freedom was also emphasized by John Chrysostom. The Jews were called sons, but failed to lose the spirit of bondage, unlike the Christians, who were saved by grace and thereby received freedom as true sons. ${ }^{35}$ Therefore the spirit of adoption received by the Christians was a far greater honor than the spirit of bondage known to the Jews. ${ }^{36}$ As regularly presented in sermons and exegetical commentaries, these ideas would probably have made an impact on any authorities familiar with the Christian religion. Even more significant, however, is their inclusion in a set of baptismal instructions authorized by John Chrysostom for use in churches subject to his jurisdiction. At various points in the instructions, the officiating priest is to remind the catechumens of how the act of baptism entails their adoption as sons of God and subsequent release from temporal bondage. ${ }^{37}$ Through their baptism, the catechumens became not only free, holy, and just, but even sons of God and joint-heirs with Christ. ${ }^{38}$ Repeated so often in such an important context, this message must have made a major impact on the thinking of Christian congregations and those with whom they interacted.

Turning to the legal sources, the first question that must be asked is what approach classical Roman law took on the question of abandoned children. Although gaps in the surviving evidence prevent us from arriving at a comprehensive reconstruction of the legal status of abandoned children prior to Constantine's acceptance of Christianity, we do know from a number of sources that the act of exposure in and of itself did not, at least in theory, affect the free or slave status of infants who had been exposed or their responsibilities to their rescuers. ${ }^{39} \mathrm{~A}$ freeborn child who was exposed and subsequently collected could again regain its freedom via the vindicatio in libertatem or return to the power of its father under the vindicatio in potestatem, whereas the slave child exposed without its master's knowledge or permission remained his property and could be reclaimed as such. ${ }^{40}$ In reality, of course, many freeborn expositi were treated as slaves, ${ }^{41}$ either because their birth status was unknown or because they were unable to prove it. Even the release of those freeborn servants whose original status was not in doubt

35. John Chrysostom, Homilia XIV in Joannem 2 (PG 59.93).

36. John Chrysostom, Homilia XIV in Epist. ad Romanos (PG 60.525-526).

37. John Chrysostom, Baptismal Instructions 2:29, 3:5 \& 5:22, in Sources Chrétiennes 50:150, $153 \& 311$.

38. Id. at 3:5, in Sources Chrétiennes 50:153.

39. Pliny Ep. 10.65-66; D. 22.6.1.2; D. 40.4.29; CJ 8.51(52).1 (224).

40. Vanzetti, supra n. 6 , at 182-183.

41. Memmer, supra n. 8, at 47. 
seems in many cases to have been made conditional on the repayment of the expenses incurred in raising them. ${ }^{42}$ Whether this repayment condition constituted a general lex de alimentis is a matter of dispute, ${ }^{43}$ but it seems to have been regularly applied for reasons of equity. The collector, therefore, was reimbursed for expenses incurred in raising the child, but the relationship between the two had no other legal significance.

So far as can be ascertained, Constantine's early legislation on abandoned children did not deviate markedly from the classical position. We know of two laws, one dating from 322 and the other probably from $329,{ }^{44}$ both of which authorize the provision of food from the imperial storehouses in an effort to assist starving parents who would not otherwise be able to support their children. These laws are reminiscent of the alimentary program developed by Trajan, although they differ in being temporary measures probably instituted in response to a particular crisis. ${ }^{45}$ Another law, ascribed to 329 in the manuscript tradition but moved to $319-20$ by Seeck, ${ }^{46}$ seems to refer to the exposure as well as the sale of newborn infants, and solidifies the classical principle that a child could be reclaimed upon payment of the expenses incurred by the rescuer or buyer in raising it. ${ }^{47}$ Notably, this permission to reclaim one's children was revoked in a constitution of 331 :

Whoever may have collected a boy or girl that was expelled from the house of its father or master with (the latter's) will and knowledge, and raised it to strength by means of his own nourishment, may retain said child in the same state that he thought to have in mind when he picked it up, that is, whether he preferred the child to be a son or a slave. All disturbance by reclaiming on the part of those who knowingly and by their own will cast newborn slave or free infants ${ }^{48}$ out of the home is to be

42. CJ 8.51(52).1 (224); CJ 5.4.16 (Tetrarchic); but see also Pliny, Ep. 10.65.6, which seems however to have been applicable only to Bithynia.

43. Vanzetti, supra n. 6 , at $184-187$.

44. CT 11.27.1-2. CT 11.27.1 (329?) is directed to Italy, while CT 11.27.2 (322) is aimed at Africa. On the dating of CT 11.27.2, see Harris, supra n. 5, at $20 \mathrm{n} .175$.

45. Judith Evans-Grubbs, Constantine and Imperial Legislation on the Family, in The Theodosian Code: Studies in the Imperial Law of Late Antiquity 135 (Jill Harries \& Ian Wood eds., Duckworth 1993).

46. Otto Seeck, Regesten der Kaiser unde Päpste 65 (J.B. Metzler 1919) (German). Seeck's view is endorsed by Vanzetti, supra n. 6, at 195, but Harris, supra n. 5, at $20 \mathrm{n}$. 179, is unconvinced.

47. CT 5.10.1. Vanzetti, supra n. 6, at 196-198, holds that "vel nutriendum putaverit" does not refer to the exposure of children, but rather to a kind of gratuitous transfer. But see Memmer, supra $\mathrm{n} .8$, at $62-64$.

48. "Liberos" could be read either as an adjective meaning "free" or a noun meaning 
completely dispelled. ${ }^{49}$

Addressed to Ablabius, Praetorian Prefect ${ }^{50}$ this constitution also makes clear that the rule preserving the birth status of abandoned children is abrogated; they are henceforth under the control of the persons who collected them, who can retain them as free children or as slaves according to their preference. The connection between collector and expositus, formerly of little or no legal significance, was now the only relationship recognized by the law.

As preserved in the Code, this constitution does not explain Constantine's motive behind providing collectors with comprehensive authority over abandoned children, which suggests that the original edict has been shortened by the compilers. ${ }^{51}$ This has not, however, prevented modern scholars from speculating about Constantine's intentions. ${ }^{52}$ Vanzetti, for example, has argued that this constitution exhibits a newfound desire to protect life at all costs, regardless of the status that children occupied, and attributes this to Christian influence. ${ }^{53}$ This argument is based on a particular interpretation of the economic effects of Constantine's reform. By specifying that exposed infants could not be reclaimed by their parents or masters and allowing the collector to keep such children in whatever status they saw fit, Constantine's new law would allegedly have had the effect of encouraging the collection of abandoned children. ${ }^{54}$ Collectors would be more willing to rescue children if they could treat them as slaves without fear of reclamation by the parents.

However, it is not clear whether this law would have actually encouraged more collection. The collector's position was hardly insecure prior to Constantine's reform, insofar as s/he could expect the return of the alimenta should the child be reclaimed. Moreover, the

\footnotetext{
"children."
}

49. CT 5.9.1.

50. Ablabius probably began his career with Constantius Caesar in Italy, but moved to the new imperial capital of Constantinople in 330 and stayed at the court of Constantine until 335 or 336. A.H.M. Jones, J.R. Martindale, \& J. Morris, The Prosopography of the Later Roman Empire Vol. 1: $A D$ 260-395, at 3 (Cambridge U. Press 1971).

51. As demonstrated by Frag. Vat. 35 and 249, Constantine's original laws, like those in the Novels appended to the CT, were usually prefaced with lengthy explanations of the reasons that led the emperor to act: see Evans-Grubbs, supra n. 2, at 45 . Honore has explained how the preamble and epilogue were systematically deleted by the Theodosian compilers. Tony Honoré, The Making of the Theodosian Code, 103 ZRG:RA 159-160 (1986).

52. Harris, supra n. 5, at 21 .

53. Vanzetti, supra n. 6 , at $188 \& 200-202$.

54. Vanzetti does not spell out this economic argument, but it seems implicit in her statement that "molto realisticamente Costantino ha creato le condizioni più adatte per mitigatre le conseguenze delle frequenti esposizioni: gli effetti giuridici vengono da sé." $I d$. at 201. 
possibility of keeping the child as a slave had always existed de facto: even in the classical period, the collector's decision to keep the child in servitude could be challenged only after the child's birth status had been legally proven.

Even if one could accept the argument that Constantine succeeded in encouraging the collection of expositi through his reform, however, there is no reason to suppose that he legislated with this purpose in mind. ${ }^{55}$ One can easily suggest other reasons that may have led the emperor and/or his consistory to change the law: they may have decided to make the law reflect what had always occurred in reality, or they may simply have been moved by the facts of a particular case of which we are unaware.

On their face, the Constantinian reforms seem to reflect little Christian influence given their direct contradiction with the Christian writers: whereas these writers had cited the enslavement and prostitution of exposed children as arguments against abandonment, Constantine specifically allows the child to be reared as a slave. ${ }^{56}$ Moreover, the notion that parents should strive to rear as many children as possible out of civic piety was scarcely a new strain in Roman thought. ${ }^{57}$ Constantine's disapproval of exposure could merely have been directed at the selfish behavior of those parents and masters who neglected to respect the interests of the state. In the absence of further evidence about the specific causes that motivated Constantine's reform, the case for a distinctly Christian impetus is tenuous. All we can say is that

55. Vanzetti claims that the emperor was likely to have been worried about depopulation of the empire as a result of war and famine, $i d$. at 187 , and similar demographic motives have been cited by others, e.g. Memmer, supra n. 8, at 66, and Harris, supra n. 5, at 21. This explanation, however, is not very convincing. On the one hand, Constantine's civil wars against Maxentius and Licinius took place nearly a generation before his decision in 331 to reform the law on expositi: any lingering effects on the population could scarcely have been significant. Regarding the other issue, Vanzetti seems to confuse occasional food crises or shortages with long-term famine: on this distinction, see Peter Garnsey, Famine and the Food Supply in the Graeco-Roman World: Responses to Risk and Crisis 6 (Cambridge U. Press 1988). The notion that the later Roman empire suffered from a long-term manpower shortage, moreover, was effectively refuted some three decades ago by Moses Finley in his review of Arthur Boak's Manpower Shortage and the Fall of the Roman Empire in the West, 48 JRS 156-164 (1958). Short-term concerns about the population of specific provinces are conceivable, as evidenced by CT 11.27.1-2, but this begs the question of how such localized concerns could lead to an edict regarding the collection of expositi that was binding for the whole empire. In any case, it is doubtful whether Constantine or the imperial officials who served under him applied such sophisticated economic analysis to legislation on exposure.

56. See Evans-Grubbs, supra n. 46, at 136. In general, the extent of Christian influence on Constantinian legislation has been exaggerated; see Evans-Grubbs, supra n. 52, passim.

57. Centuries before Constantine, for example, it was emphasized by the Stoic philosopher Musonius Rufus. See Boswell, supra n. 7, at 86-88. 
Constantine's reform strives to assure others that exposure is wrong.

Following the reform of Constantine, the next legal reference to exposure that has come down to us apparently dates from the reign of Valentinian $\mathrm{I}^{58}$ It focuses more on the duty of parents not to abandon their children than on the rights or responsibilities of rescuers. Declaring that each and every person must nourish his or her own offspring, a constitution of 374 subjects those who fail to do so to "the punishment that had been laid down."59 Opinions differ on the significance of this last phrase,$^{60}$ but it has been frequently considered alongside a law, issued one month before, specifying that any man or woman who committed the piaculum, or "sin that requires expiation," of killing an infant, was subject to capital punishment. ${ }^{61}$ Uncertainties about the original context and content of these laws make it difficult to draw any conclusions about their significance. If Valentinian did in fact outlaw child exposure and infanticide in 374 , this could reflect the influence of contemporary Christian thinkers such as Lactantius; indeed, the use of the word piaculum in the law of infanticide does suggest

58. The extant text is probably corrupt. As preserved in the Code of Justinian, CJ 8.51(52).2 (374) reads:

Unusquisque subolem suam nutriat. quod si exponendam putaverit, animadversioni quae constituta est subiacebit. $\S 1$. Sed nec dominis vel patronis repetendi aditum relinquimus, si ab ipsis expositos quodammodo ad mortem voluntas misericordiae amica collegerit: nec enim dicere suum poterit, quem pereuntem contempsit.

Sec. 1 of the text, however, is virtually identical to the beginning of CT 5.9.2 (412): "Nullum dominis vel patronis repetendi aditum relinquimus, si expositos quodammodo ad mortem voluntas misericordiae amica collegerit, nec enim dicere sum poterit, quem pereuntem contempsit." This suggests two possibilities: either the author of the Honorian constitution copied the language used in an earlier constitution of Valentinian, or the Justinianic compilers conflated the two constitutions in their Code. The latter view, held by Vanzetti, supra $\mathrm{n}$. 6, at 215-216, seems to me more probable. Such a reference to reclaiming by masters and patrons would be more natural in a constitution that alters the procedure for registration of expositi than in a criminal law about the act of exposure itself, although it is not clear why the Justinianic compilers would have inserted it in the latter. The phrase "voluntas misericordiae amica collegerit," moreover, is reminiscent of Sirm. Const. 5, unquestionably attributed to Honorius's reign, although the latter constitution differs in content from CT 5.9.2, as discussed below. I have therefore not treated $\S 1$ of CJ $8.51(52) .2$ in my discussion of Valentinian's legislation. If the phrase does in fact date from Valentinian, this would move the inception of the rhetorical trends discussed below from the early fifth to the late fourth century, but would not otherwise affect the argument.

59. CJ 8.51(52).2 (Mar. 374).

60. Emiel Eyben, Family Planning in Graeco-Roman Antiquity, 11-12 Ancient Socy. 31 (1980-81), and Harris, supra n. 5, at 22, suggest that the penalty specified in CJ 8.51(52).2 is "probably" a reference to capital punishment. Boswell, supra $\mathrm{n}$. 7, at 162-163, gives little weight to this interpretation. The statement of $\mathrm{H}$. Bennet, The Exposure of Infants in Ancient Rome, 18 CJ 351 (1923), that exposure was made a capital crime in 374 is too categorical.

61. CT 9.14.1 (Feb. 374). It is difficult to believe, however, that infanticide and exposure could have been viewed as equivalent, since exposure did not always result in the death of the child. 
moral outrage rather than civic self-interest. ${ }^{62}$ Without knowing for certain whether the earlier constitution on infanticide was somehow linked to the later regarding parental duties and exposure, however, it is difficult to cite emotional language in the infanticide constitution as evidence of similar concerns in the abandonment law. And, as in the case of Constantine's legislation, the notion that parents had some kind of civic obligation to rear their children was not peculiar to Christianity; any suggestion of Christian influence behind the decision to enforce such a duty must remain speculative.

From the beginning of the fifth century, however, it is possible to discern a tendency reminiscent of Christian teaching in the rhetoric, if not the content, of the surviving legislation on exposure. The first law demonstrating this trend was issued by Honorius in 412 and addressed to Melitius, Praetorian Prefect:

We leave no approach of reclaiming to masters or patrons, if good will, the friend of compassion, collected those exposed by a certain means to death (si expositos quodammodo ad mortem voluntas misericordiae amica collegerit), for no one can call his own that which he scorned when it was perishing: if only the signature of a bishop as witness should follow, concerning which for the purpose of security there can be no delay. ${ }^{63}$

While the first part of this edict adds nothing substantive in practice to Constantine's reform apart from mentioning patroni as well as domini, ${ }^{64}$ the rhetoric of the edict suggests a change in thought about the status of abandoned children. To be sure, the procedural change in the second section, which orders the registration of collected infants with a bishop, has been downplayed by Memmer, who argues based on the Sententiae Syriacae that some such registration had been required even under Constantine. Memmer claims that all Honorius did was substitute an episcopal for a civil authority. ${ }^{65}$ Whatever this change may tell us about the effectiveness of the Church as an administrative body in the fifth century, it does not in itself point to any major ideological shift in the perception of abandoned children.

What is different about this constitution, however, is the rhetoric of the first sentence, in particular the phrase "si expositos ... misericordiae amica collegerit." This emphasis on the gracious act performed by the collector is new in late imperial legislation on abandonment: There is no

62. Harris, supra n. 5, at 21-22.

63. CT 5.9.2.

64. Vanzetti, supra n. 6 , at 216

65. Memmer, supra n. 8, at 92. 
trace of it in Constantine's reform, which speaks only in general terms of the provision of alimenta that causes the child to grow to strength. ${ }^{66}$ The use of the term misericordia (compassion) in Honorius's law is particularly interesting. This word does not appear in any surviving imperial constitutions until the Christian period, where it is frequently used in the phrases "divina misericordia" or "misericordia dei." 67 It does not require a great deal of imagination to see such language as reflecting religious sentiment and origins. ${ }^{68}$

Similarly interesting is another constitution of Honorius dated seven years later and preserved in the Sirmondian Constitutions. Although the case for specifically Christian language is less strong, this constitution recognizes the value of the rescued child:

It is defended with shameless artifice, if those persons are reclaimed toward their condition or origin, for whom in time of famine, when they were compelled toward death by scarcity, their master or patron had not been able to provide assistance. But it is moreover unjust, if some person should dare hoping by some title to vindicate as indebted to him a man kept alive (servatum hominem in lucem) by another's expenses. Therefore, when the series of events has been inspected concerning those who through necessity were procured or perhaps collected, let Your Magnificence see to it that they continue in their ownership; or if they are clamored for by someone, only when twice the amount has been paid out which was given in the name of a price and the expenses have been considered do we permit them to return to the authority of the one who is vindicating them, lest it be a pitiable thing thus to have furnished nourishment to one who is dying (ne sit miserum ita exhibuisse alimoniam morienti), in that another

66. CT 5.9.1 (331); see above.

67. Apart from the dubious constitution CJ 8.51(52).2 discussed above, the word misericordia in all its forms appear only 5 times in the Code of Justinian according to Robert Mayr, Vocabularium Codicis Iustiniani, I: Pars Latina (Hildesheim 1965). Four of these instances date from Justinian (534) and are paired with references to God and the divine (CJ 1.27.1.7 "deus . . . suam misericordiam"; CJ 1.27.1.8 "dei misericordiam"; CJ 1.27.1.10 "deus ... per ipsius misericordiam"; CJ 1.27.2.4a "divina misericordia"); all of them are included under the heading "De officio praefecti praetorio Africae ..." The other usage is from a constitution issued by the emperor Justin in 519 on the subject of natural children (CJ 5.27.7.1). The word is never used in the pagan constitutions. One might be able to extend this argument by examining the Digest, but I have not dared to do so because of additional problems of interpolation: see David Johnston, Justinian's Digest: The Interpretation of Interpolation, 9(2) Oxford J. Leg. Stud. 149166 (1989). Whether the phrase including misericordia might have been interpolated in CT 5.9 .2 by the Theodosian compilers is an interesting question, but one for which I am not prepared to suggest an answer.

68. The word appears in Lactantius, Divine Institutes 6.20 (PL 6.708-9), but one would hesitate to suggest this as the inspiration for Honorius's law. 
person would profit from someone kept alive (servatus in vitam) at the collector's expense. ${ }^{69}$

It is unclear whether this constitution, which mentions both sale and exposure, repeals the Constantinian reform since it sets forth a new procedure for reclaiming. ${ }^{70}$ More important than the substance of the law, however, is the manner in which it expresses itself. Exposed children are not merely "raised to strength" by the one who collects them, but are literally "saved into the light": the collector has "furnished nourishment to one who is dying.,"71

Of course, the use of the word servatum to describe the one who has thus been kept alive does not necessarily betray Christian sentiment: a quotation from Florentinus preserved in Justinian's Digest, for example, derives the word servus (slave) from the practice of "saving" prisoners of war by selling rather than killing them. ${ }^{72}$ Still, with the word miserum, the author of Honorius's law has without explanation used an emotionally charged term, no doubt selected to convey the simple fact that the collector's efforts ought to be recompensed. Though the use of miserum in this second constitution is not quite as suggestive as the misericordia of the first, it is worthy of notice. If a case for Christian influence in this area of imperial legislation is to be made, it must surely begin with these two constitutions of the fifth century.

Apart from the two laws of Honorius, we do not possess any imperial legislation from the fifth century that deals directly with exposure. In light of this rhetorical trend, however, it is interesting to note the following ecclesiastical canon issued by the Council of Vaison in 442:

Concerning the exposed, because a complaint goes forth having been cried out by all that they are exposed not to compassion (misericordiae) but to wolves, and the human mind, although affected by the precepts of compassion (quamuis inflexa praeceptis misericordiae), fails to collect them out of fear of false accusations, it seems that it must be observed, according to the statutes of the most faithful, pious, and august emperors, that whoever collects an exposed child must call the church to witness, acquire the testimony: nevertheless on Sunday let the priest announce from the altar, that the church might know that an exposed person has been collected, so that within ten days from

69. Sirm. Const. 5 (419).

70. Vanzetti, supra $\mathrm{n}$. 6 , at 218 , thinks that the procedure of reclaiming outlined in the latter part of the law cannot relate to exposure, but see Memmer, supra n. 8, at 75 n. 190.

71. CT 5.9.1 (331).

72. D. 1.5.4.2. 
the day of exposure, if someone shows himself to acknowledge it, let him receive the exposed child: with the pity (misericordia) for those ten days to be paid back to the collector as he should prefer, either in the present by man, or in the hereafter with the grace of God. $^{73}$

Issued three decades after the first constitution of Honorius, this ecclesiastical law makes reference to the statuta . . principium, but it is not clear whether it means to include the law of $412 .^{74}$ This canon was followed by the specification that those who acted in contravention of it are subject to the ecclesiastical penance for murder, ${ }^{75}$ and its regulations were reaffirmed by two later Gallic councils. ${ }^{76}$ Apart from the practical provisions set forth in this law, the rhetoric it employs is quite interesting, in particular its frequent repetition of the word misericordia to describe the emotion that led the collector to act. This word necessarily calls to mind the first law of Honorius, and could be a sign that the author of that constitution and the church representatives at Vaison shared a common understanding of the motive that led the collector to act. ${ }^{77}$ Fifth-century legislators and clerics may not have been of one mind regarding the problem of exposure, but their rhetoric suggests that they were thinking along similar lines.

Bearing in mind this fifth-century emphasis on the misericordia of the collector, Justinian's reform falls more clearly into focus, although its status as a legislative and ideological milestone remains undiminished. In two successive constitutions, ${ }^{78}$ Justinian, or rather his legal secretary Tribonian, ${ }^{79}$ reversed the Constantinian rule on the

73. Conc. Vasense Can. 9, Corpus Christianorum, Ser. Lat. 148: 100-101.

74. Vanzetti, supra n. 6, at 216-217, argues that this canon spells out the procedure whereby the testis episcopalis mentioned in CT 5.9 .2 was to be obtained. This is disputed by Boswell, supra $\mathrm{n} .7$, at $173 \mathrm{n} .115$, whose arguments however are not convincing.

75. Conc. Vasense Can. 10, Corpus Christianorum, Ser. Lat. 148:101.

76. Conc. Arelatense Secundum Can. 51, Corpus Christianorum, Ser. Lat. 148:124; Conc. Agathense Can. 24, Corpus Christianorum, Ser. Lat. 148:204.

77. It might also be cited as an argument in favor of the view that the statuta referred to in the canon include CT 5.9 .2 (412), though this is conjectural.

78. CJ 8.51(52).3, issued in 529 and summarized in CJ 1.4.24; Nov. Just. 153, issued in 541.

79. CJ $8.51(52) .3$ is among the laws ascribed by Honoré to the beginning of Tribonian's quaestorship in 529. Tony Honoré, Tribonian 106 (Duckworth 1978). Nov. Just. 153 is also alleged to fall within Tribonian's tenure of office, although its use of Greek to specify a fine runs contrary to Honoré's theories about Tribonian's style, id. at 130-137. Honoré's view of the preeminent role played by Tribonian in the drafting of legislation may be somewhat exaggerated. See Michael Maas, Roman History and Christian Ideology in Justinianic Reform Legislation, 40 Dumbarton Oaks Papers 17, 27 (1986). But Honoré suggests that Tribonian was a Christian, Honoré, op. cit. at 65-67, and whether the reform measures passed during Justinian's reign primarily reflect the views and rhetoric of the emperor or his quaestor would not thereby affect the question of Christian influence. In any case, the laws should be judged by their content, not according to preconceived notions about those responsible for drafting them. 
treatment of expositi and decreed that no exposed child, regardless of its birth status, could be held as a slave, colonus, adscripticus, or freedman: henceforth, all exposed children were to possess the rights and privileges of freeborn men. The constitution is innovative by any reckoning, and cannot be called a return to classical principles, for it goes beyond all classical precedent in permitting even slave children to become free through the act of exposure. ${ }^{80}$ The language used to justify such measures is familiar, as shown in the first reform constitution of 529:

... Those who, with the reason of piety persuading them (pietatis ratione suadente), picked [exposed infants] up, will not be suffered to change their own opinion and retain them in servitude, even if they started out in the beginning having a thought of this kind, lest their doing such a pious act might seem akin to a contract of buying and selling (ne videantur quasi mercimonio contracto ita pietatis officium gerere) ${ }^{81}$

The pious deed of the collector is also referred to in the second reform constitution. $^{82}$

Like the surviving fifth-century laws, Justinian's reform focuses on the compassion of the collector that led him or her to save the life of the child. Unlike preceding legislation, however, Justinian's constitutions take this mental construction to its apparent logical conclusion: if the collection of an exposed infant is an act of piety, then it cannot lead to the enslavement of the child. Whether Justinian or his secretary had Romans 8:12-17 in mind when they drafted their law is a matter for conjecture, but the parallel is indeed suggestive. Just as the spirit of adoption rescued the Christian faithful through God's grace, so did the collector's act of compassion save the life of the exposed. In both cases, the beneficiary "did not receive the spirit of slavery to fall back into fear, but ... the spirit of sonship." 83 Adoption into slavery was no adoption at all.

Justinian's legislation, despite its good intentions, is likely to have had little practical effect. Only the privileged few would have been able to plead their case at law, and it must have been difficult for a servant to

80. Justinian's reform actually had two provisions: the first affirming the established rule that former masters and patrons could not reclaim those exposed with their knowledge or consent, and the second breaking precedent by preventing the collector from retaining the child in a position of servitude. The first aspect of the reform is indeed harmonious with classical ideas (Suetonius, Claudius 25; cf. CJ 8.51(52).1), and this connection is drawn in Nov. Just. 153. The provisions relating to the collector, however, are completely novel.

81. CJ 8.51(52).3.

82. Nov. Just. 153

83. Rom 8:12-17. 
prove that he or she had been exposed. In any case, the very fact that the original reform was reissued twelve years later could be adduced as evidence that few exposed infants were protected from slavery as a result of the new law. ${ }^{84}$ To chastise Justinian on the grounds that his laws did not produce effective results, however, would be to miss the point. There is some value to expressing moral principles through legislation, regardless of its practical effects.

An example drawn from modern law may serve to illustrate this. In recent decades, the practice of inter-country adoption has come to be seen as a possible solution to the plight of orphaned children in developing countries; yet this phenomenon has also given rise to legitimate concerns. ${ }^{85}$ The Supreme Court of India, for example, handed down a decision in 1984 that contained a number of guidelines designed to protect children adopted by foreign nationals from exploitation. ${ }^{86}$ One of its provisions dealt with exorbitant fees being charged to foreign adoptive parents by adoption agencies, a practice that was seen as akin to trafficking in children. The court specified a maximum rate at which the agency could bill the parents for legitimate maintenance and medical expenses. ${ }^{87}$ These sentiments were echoed five years later in the landmark UN Convention on the Rights of the Child. Declaring that the system of adoption must be regulated in a manner so as to "ensure that the best interests of the child shall be the paramount consideration," the signatories promised to "take all appropriate measures to ensure that, in inter-country adoption, the placement does not result in improper

84. Boswell, supra n. 7, at 191; see also Miller, supra n. 5, at 152.

85. See e.g. D. Marianne Blair, Safeguarding the Interests of Children in Intercountry Adoption: Assessing the Gatekeepers, 34 Cap. U. L. Rev. 349, 353 n. 18 (2005) (citing recent literature); Bridget M. Hubing, International Child Adoptions: Who Should Decide What Is in the Best Interests of the Family, 15 Notre Dame J.L., Ethics \& Pub. Policy 655, 663-667 (2001) (discussing arguments for and against intercountry adoption); Solangel Maldonado, Discouraging Racial Preferences in Adoptions, 39 U.C. Davis L. Rev. 1415, 1420-1430 (arguing that race plays a role in the decisions of Americans to adopt children from abroad); Elisabeth J. Ryan, Note, For the Best Interests of the Children: Why the Hague Convention on Intercountry Adoption Needs To Go Farther as Evidenced by Implementation in Romania and the United States, 29 B.C. Intl. \& Comp. L. Rev. 353, 363-374 (2006) (discussing the Hague Convention on Intercountry Adoption and its pending ratification in the United States); David M. Smolin, The Two Faces of Intercountry Adoption: The Significance of the Indian Adoption Scandals, 35 Seton Hall L. Rev. 403, 450-474 (2005) (discussing recent scandals in Andhra Pradesh, India).

86. Laxmi Kant Pandey v. Union of India (1984) (citing Nirmala Pindat, Inter-Country Adoption: The Indian View, in Parenthood and Modern Society: Legal and Social Issues for the Twenty-First Century, 268 (John Eekelaar \& Petar Sarcevic eds., Martinus Nijhoff 1993)). The decision resulted in the creation of a Central Adoption Resource Agency in 1990, which plays a comprehensive regulatory role in matters relating to adoption in India. See Smolin, supra n. 88, at 443-445.

87. Eekelaar \& Sarcevic, supra n. 88 , at 272. 
financial gain for those involved in it." ${ }^{188}$

What the UN delegates may have ignored, however, is that a certain school of thought has held for some time that legalizing the sale of newborn infants might reduce the glut of children in foster care while eliminating the long queues faced by prospective adoptive parents. ${ }^{89}$ This proposition has met with its share of criticism. ${ }^{90}$ In any case, it is not at all clear whether the perceived economic benefits conceived with regard to adoption within one country would still hold across international borders. Nevertheless, accepting for the sake of argument the notion that a deregulated international market would be the most effective way to match adoptive parents with children, one might be led to conclude that the UN Convention acted against children's economic interests.

If the various modern legislative bodies that have prohibited international commerce in children out of an expressed concern for their interests were not contradicting themselves, however, perhaps the "interests of the child" must be defined in a less mathematical fashion. ${ }^{91}$ Only the most cynical analyst would argue that the UN Convention actually intended, by placing restrictions on profiteering by adoption agencies, to keep suffering children from prospective loving parents. Aside from the question of whether the notion of a market in newborn infants is economically sound, it is highly unlikely the legislators adhered to such a limited economic definition of "interest" when they acted to prevent children from being sold.

If all laws were judged on the basis of their immediate practical consequences, one would have to conclude that the UN Convention of the Rights of the Child served little purpose, since few children in developing countries could hope to avail themselves of its many generous provisions. The significance of the UN Convention, like all grand statements of legal principle, ultimately derives not from its direct

88. Convention on the Rights of the Child, G.A. Res. 44/25, U.N. GAOR, 44 Sess., U.N. Doc. A/44/49 (1989), entered into force Sept. 2, 1990.

89. Elisabeth M. Landes \& Richard A. Posner, The Economics of the Baby Shortage, $7 \mathrm{~J}$. Leg. Stud. 323-339 (1978), defended in Richard A. Posner, The Regulation of the Market in Adoptions, 67 B.U. L. Rev. 59-72 (1987).

90. For some criticisms, see J. Robert S. Prichard, A Market for Babies?, 34 U. Toronto L.J. 347-355 (1984); but see Michele Goodwin, The Free-Market Approach to Adoption: The Value of a Baby, 26 B.C. Third World L.J. 61, 65 (2006) (arguing that there is a "de facto, largely unregulated, adoption free market" already in place).

91. The notion of legislative "interest" is an ambiguous one, and cannot easily be delineated in purely economic terms. Even the most refined and inclusive economic model cannot capture all the direct and indirect effects of a particular law, and attempts to derive the intention of the law from its perceived economic results or vice versa can lead to absurd conclusions. 
results, but from its place in the history of legal thought, and the Convention has certainly provoked debate. ${ }^{92}$ Justinian's reform, which arguably took fifth-century ideological trends to their logical conclusion and found a new way to consider the "interests of the child," ought to be evaluated along similar lines.

92. See e.g. Children, Rights, and the Law (P. Alston, S. Parker, \& J. Seymour eds., Clarendon Press 1992); David M. Smolin, Overcoming Religious Objections to the Convention on the Rights of the Child, 20 Emory Intl. L. Rev. 81 (2006). A conference held at the University of Ottawa from March 15-17, 2007, addressed the many issues that have arisen with respect to the Convention since its adoption. 
